\title{
Structural Changes in Livestock Production: A Case Study in Montenegro
}

\author{
Goran Rajović ${ }^{1, a}$, Jelisavka Bulatović $2, b$ \\ ${ }^{1}$ Street Vojvode Stepe 252, Belgrade, Serbia \\ Phone: 0038161/19-24-850 \\ 2Department of Technology and Management, College of Textile Design, \\ Street Starine Novaka 24, Belgrade, Serbia \\ Phone: 003861/ 3082651 \\ a,bE-mail address: dkgoran.rajovic@gmail.com , jelisavka.bulatovic@gmail.com
}

\begin{abstract}
The production structure of agriculture in Montenegro, livestock production has a very important role, because without a stable and developed livestock production has not developed agriculture. Therefore, in this paper, shows structural changes in livestock production. In fact, in the period 1960 2010 , the total number of agricultural farms that raise cattle has been reduced from 64.918 to 32,675 agricultural farms. Which is after all result of social and economic factors, such as: processes of industrialization and urbanization, depopulation of rural areas, reduced local and regional market, the low purchasing power of the population, transition, privatization, the lack of long-term development strategy for livestock, technological and technical unwillingness processing capacity, lack of organization of primary production, weak linkage of farmers and processors, insufficient and slow recovery cattle breeds. Judging by the number of agricultural farms that raise cattle, production volume, and towards other indicators, livestock production in Montenegro mainly used to meet the needs of households. Smaller part of are intended market. To meet these problems were resolved in an adequate way, it is necessary to bring appropriate strategy in livestock Montenegro with the proposed development measures which must be long term. Agriculture Development Strategy should clearly define macro-zones on which to foster specific livestock species, and based on that subsidizes and assists farmers and households. Law concerning land is necessary to clearly specifies, it is defines the terms of use and disposition of land for the purpose of food production. It should be clear that the specifies how and under what conditions will be used state lands, what about the natural meadows and pastures, by taking advantage of available forest land for livestock.
\end{abstract}

Keywords: Montenegro; livestock; agricultural farms; production

\section{INTRODUCTION}

Montenegro is a state located in Southeastern Europe who lies on coast Adriatic Sea. It is bordered to the east and northeast with Serbia to the west and northwest Croatia and Bosnia and Herzegovina and on south-east with Albania. In the southwest is the Adriatic Sea is shared of Italy. Montenegro is at about $5.00 \mathrm{~km}$ from Rome, $1.500 \mathrm{~km}$ from Paris and Berlin and about $2.000 \mathrm{~km}$ west of Moscow. 
It lies on the Balkan Peninsula at the very heart of Europe. It spreads between $41^{\circ} 51^{\text {' }}$ and $43^{\circ} 30^{\prime}$ north geographic width and between $18^{\circ} 26^{\prime}$ and $20^{\circ} 21^{\prime}$ eastern geographic length. It covers surface area of $13.812 \mathrm{~km}^{2}$ and according to statistics from the 2011 in Montenegro hosts 620.029 inhabitants. Per territory size of Montenegro in Europe are only fewer countries: Andorra, Liechtenstein, Luxembourg, Vatican, Monaco and San Marino [1].

Agricultural land due to their stationing and qualitative characteristics representing are favorable base for the development of agriculture in Montenegro. However, analysis of the research below shows that livestock production is not in conformity with all available natural and social conditions [1-2].

Incompatibility between the available potentials and modern livestock production is determined by the global economic policy, tradition, demographic trends, economic structure, market ... [3-4]. In fact, in the territory of Montenegro insufficient attention was paid to the problems of agricultural development, especially the choice of the optimal structure production. Former way management (small plots, out of date processing land, uncoordinated structure of production), not in the agricultural development [5-7]. According to the data of the Statistical Office of Montenegro [8] total agricultural land in Montenegro in 2011 amounted to 515749 ha, of which arable surfaces make 189144 ha, arable land and gardens 45.748 ha, orchards 12.007 ha, vineyards 4.399 ha, 126.990 ha meadows, grasslands 323.953 ha, ponds, fishponds and reed 2.643 ha.

According Doderović and Ivanović [9], forests and forest land cover an area of 738,000 hectares or $53.4 \%$ of the total area. Of this, the forest vegetation is 622,000 ha or $45 \%$. This percentage of forest cover assessed as great advantage in terms of protection and improvement of the environment. Higher respect agriculture as a primary activity, I can the exploit comparative advantages of Montenegro.

The cycle of economic activities can best be initiated and run if the first approach to investing in the development of agriculture, because it as a sector of economic disposes the most resources [10-11]. These resources is needed wise and rational to use. Livestock production, as part and one of the most important parts of agricultural production and the area with the fastest turnover of capital in agriculture, directly depend on all the parameters that influence the market, either at the macro or micro level [12-13].

\section{RESEARCH METHODOLOGY}

Two basic group's data sources were we in the study. The first group includes sources statistical data on livestock, available to of the Statistical Office of Montenegro. The second group of data is results of previous studies. The focus of the research was on main activities of livestock: sheep, cattle, goat, pig, poultry, horses and bees. Although livestock Montenegro has potentially great development opportunities, current development is characterize by a continuous and extreme decrease.

Analysis of livestock in this article includes structural changes in livestock production. In this paper is been used: a comparative, descriptive method, the method of theoretical analysis, a statistical method. 


\section{ANALYSIS AND DISCUSSION}

Livestock breeding is the most important branch of agricultural production. The degree of intensification of agriculture is measure by his share of this sector in total value of agricultural production [14-15]. Compared with agrarian developing countries, Montenegro is significantly lagging behind by any measure of development of livestock production (number of heads of cattle breeding, the total volume of livestock production ...) [16-17].

In considering function of livestock in the process of social reproduction [18-19], emphasize its multiple role by meeting the following objectives: (1) livestock is the first phase of processing of primary agricultural production, in which the inputs are relatively low values transform into outputs multiple values (2) the production of manure, livestock provides intensive vegetable production, (3) cultivation of fodder crops like stubble crops in temperate continental conditions allows the rational use of arable land, (4) The breeding of livestock are processed and refined certain herbal products that otherwise would not be able to use, (5) the production of high value products covering livestock is an important part of the dietary needs of people, (6) the development of several branches of the food industry based on raw materials that come from livestock production, (7) livestock farming is the "stabilizer" of agriculture by reducing fluctuations in agricultural production, (8) hiring with additional human labor, animal husbandry is the source of income of the population, (9) livestock farming allows acceleration crafts resources in agriculture and their balanced flow, (10) animal products contain high-value protein for human consumption.

Statistical data about the motion of livestock and agricultural production it is hard to obtain because of a lack of proper statistical material. This means that the statistics are not addressed enough attention on status of livestock and livestock production in the former Yugoslavia, without of such material is impossible to give an overall overview of agricultural production. Therefore, for the analysis of structural changes in livestock production in 1960 and 1969 as well as the time period 1964/68 used the data of the Institute of Agricultural Economics, Belgrade [20], data Kalezić [21], which facilitates their comparison. For 2010 structural changes in livestock production, we have looked at on the data of the Statistical Office of Montenegro [22]. Due to the lack of data for the production of meat in Montenegro in 2010, we used the data of the Statistical Office of Montenegro [22] in 2001/02. Before than we approach view the current state of animal husbandry in Montenegro, it is important to stress that livestock farming is a significant potential for agricultural development, but is underdeveloped in relation to natural resources and the demands of intensive agricultural production [23-25].

In the period 1960-2010, the number of livestock units of livestock in Montenegro was reduced from 133.773 on $117.753,1$ or for 16.020 livestock units. "Oscillation in the number of livestock units of livestock during this period are the result of economic factors that have influenced the development of individual branches of animal husbandry, such as: extensive character, throat low productivityprimitive way management ... "[26].

Analysis of agricultural farms according to the number of livestock units, indicating are different tendency. In fact, the total number of agricultural households in 2010(32.675), they 32.656 its disposal about 117.753,1 conditional throat livestock, while a total of 19 businesses its disposal of 4.891,2 conditional throat livestock. Therefore, the family agricultural holdings are relatively small and mixed livestock production from 3.6 conditional throats per holding, while businesses have 257,4 conditional throats per holding. Numerically movement of agricultural holdings, which are reared of livestock, was different. 
The 64.918 agricultural households in Montenegro in 1969, dealt with the breeding of livestock (cattle, sheep and pigs). While is in 2010 there were only a 32.675 agricultural farms who the dealt breeding livestock. Thus, compared to 1969, the number of agricultural households in Montenegro that dealt with breeding livestock decreased by 32,243 agricultural holdings or to 49,67\%. In Livestock Montenegro are dominated cattle and sheep. On 100 ha of agricultural land (total acreage of Montenegro is 515.740 ha), comes 44,1 sheep, 15,6 cattle, 9,2 pigs, 6,9 goats, 0,8 horse which is certainly not enough compared on potential possibilities of Montenegro.

Sheep production is by throat the most important livestock activity in Montenegro. Basis of development of are livestock sector, which are meadows and pastures (540. $943 \mathrm{ha}$ ). Development of sheep at the same time determined and demand for wool in domestic traditional manner. However, in the analyzed period 1960 - 2010 the total number of agricultural holdings engaged breeding of sheep, was reduce from 38.942 agricultural holdings on 6.088 or $84.37 \%$. Tomić [27] can explain this: labor shortages, poor economic conditions, primitive ways of livestock raising, alienation lambs for slaughter with low mercury measure up to $15 \mathrm{~kg}$, which reflects unfavorably on economic returns, low purchase price of lambs, sheep, hides, and wool. From a total of 32,675 agricultural holdings engaged livestock production in 2010, 6,088 agricultural holdings raising sheep, of which 6.082 family agricultural holdings (the total number of sheep from 226.752 heads), while only 6 business subjects raising sheep (2.285 throat)which is $0.1 \%$ of the total number of farms that raising sheep. The average number of sheep per family agricultural farm is 37,3 necks in relation to the total number of family agricultural holdings who raising sheep, while the average number of sheep business subjects ten times higher, or is 380,1 throat by business subject who raising sheep. In racial composition of the sheep are prevalent: "shep pramenka", "sjenicka sheep", "bardoka", "žuja", mongrels. According Gutić et al [28] beer sheep is an autochthonous pramenka that since ancient times cultivated in Montenegro. The body weight of sheep ranging from $50 \mathrm{~kg}$ to $52 \mathrm{~kg}$, and the rams from $62 \mathrm{~kg}$ to $65 \mathrm{~kg}$. Per year gives of wool, on average, 1,3 $\mathrm{kg}$ to $1,5 \mathrm{~kg}$ in sheep and $1,8 \mathrm{~kg}-2 \mathrm{~kg}$ in rams. "Pivski" breed sheep for 200 days gives about 110 liters of milk.

Prolificacy of ewes ranges from 110-120\%. "Sjenička" sheep is one of the largest of strains pramenka. The body weight of sheep is on average $45 \mathrm{~kg}$ and $60 \mathrm{~kg}$ of rams. Annual amount of wool in sheep was $1.4 \mathrm{~kg}, 2 \mathrm{~kg}$ and of rams. Average milk production in lactating sheep "sjenicka" is 5-6 months ranges from 601 to 801 , including the milk that lamb suck on. Of the 100 sheep will produce be 110-13o lambs. "Bardoka" is an autochthonous breed sheep. Body weight of sheep ranged from $38 \mathrm{~kg}$ to $45 \mathrm{~kg}$ and the rams of $60 \mathrm{~kg}$ to $67 \mathrm{~kg}$. Annual amount of wool in sheep ranged from $1,5 \mathrm{~kg}$ to $2,0 \mathrm{~kg}$, and $2.5 \mathrm{~kg}$ of rams around. The modest breeding conditions yield an average of about 100 liters of milk, including the amount that lamb suck on (for 6 months of lactation). Fertility "bardoka" is poorly expressed. Of are 100 of sheep gets to 105 lambs. "Žuja" is domestic breed of sheep, which threatens with extinction. Experts in the field of agro-economics emphasize the there is no economic calculations for her farming, while men which hold this breed ewes and trying to save the vanishing point that is him out of love.

The quality of wool is variable, mostly unsatisfactory. Lactation lasts 5-6 months and average daily milk produced $7 \mathrm{dl}$ (sometimes 2 liters per day). Her lambs are easier weight. So, in terms of racial composition of sheep in Montenegro "pramenka" prevails with several local indigenous strains while the share of highly productive throat in pure breed very low, almost negligible. The total population is very high share of crossbreds $(40 \%)$. These are crossbreds between local strains "pramenka" and crossbreds "pramenka" more productive breeds, 
primarily Württemberg. From the production of meat, especially are significant crossbred's "sjenicka pramenka" and Wurttemberg, who are the most numerous. Previously, sheep production in Montenegro characterized triple production features: meat-milk-wool. How wool is practically lost economic importance, we can only talk about dual-purpose: meat-milk. It is estimating that the ratio of the value of these products: $65-70 \%$ meat, milk and $30-35 \%$, depending on area, production and milk production [29]. According to the data of the Statistical Office of Montenegro [22] during 2001/02. godine in Montenegro produced 8,500 tons meat of sheep. Data of the Statistical of Montenegro [8] indicate that in 2011 produced 8.830 (ooo 1) sheep's milk, with an average milk production of 79 liters per milking sheep throughout the year. Wool production in 2012 reached is 275 tons. Average yields are about $1.5 \mathrm{~kg}$ per sheep. Most of the wool produced is use in private houses; much smaller part is place on the market.

Of bovine animals are by the number of livestock, livestock other activities in Montenegro. However, the total number of agricultural holdings involved in bovine animals breeding, in the time 1960 year, 2010 has been reduce from 55.560 agricultural holdings on 24.624 or 55, $68 \%$. Thus, 24.624 agricultural holdings grow bovine animals in 2010, only the 8 business subjects. The total number of cattle that are bred is 80.209 , of which 78.633 are owned by family agricultural holdings (or $98,04 \%$ of the total number of cattle), and 1.576 owned businesses subjects (or 1,96\% of total cattle). The average number of bovine animals per family agricultural farms that raise cattle heads is 3,3 , while the average number of bovine animals per business subject who raise cattle 197 throat. Of the total number of cattle, 7.059 head of bovine animals were grazing on common land (commune, Katun), which represents $8.8 \%$ of the total number of bovine animals. Cattle are mostly the grown for getting milk, dairy products and meat, as well as to obtain organic fertilizer. The racial composition is dominant have by bush, color Brown alpine cattle, Holstein, Simmental, gray Tyrol, mongrels. Bush also known as the domestic cattle or Illyrian mountain ox. Bush and its crossbreds are located in undeveloped mountainous regions of Montenegro. Cow is body weight of $180 \mathrm{~kg}$ to $250 \mathrm{~kg}$ and $300 \mathrm{~kg}$ bull. The calves are small, after calving masses are about $15 \mathrm{~kg}$. Lactation lasts for 9 months and gives about 1.000 liters of milk. The amount of milk production varies considerably depending on the conditions of keeping and feeding, so that they can get up to 1,500 liters per cow. A lot of good fertility and disease resistance characterizes it. By are crossing drilled and work on improving production performance caused by other races as "gatačko "cattle. Alpine burns cattle, is adapted to the hilly and uneven terrain of Montenegro. Provides up are to $6.000 \mathrm{~kg}$ of milk per year. Weight cows from $550 \mathrm{~kg}$ to $750 \mathrm{~kg}$ and the weight of the bull of $1.000 \mathrm{~kg}$ to $1.200 \mathrm{~kg}$. Holstein cattle are provides about $10,000 \mathrm{~kg}$ of milk in one lactation. Cows in the body weight of $650 \mathrm{~kg}$ to $700 \mathrm{~kg}$. Holstein best suited to the production of large, modern dairy farms. Tyrol gray of cattle is typical mountain cattle breeds.

These cattle are simple, modest demands are, they have a strong instinct to find food in the pasture and have the capability of efficient conversion of even coarse vegetation. Cows of this breed are medium sized, good fertility and longevity. Provide up to $5.000 \mathrm{~kg}$ of milk per year. Breeds of beef cattle are unfavorable, because the estimates of the Biotechnical Institute in Podgorica, various crossbreeds account for $50 \%$ of the total population. Gray Tyrolean cattle accounted for $15 \%$, while highly productive breeds and Holstein brown cattle together account for about $32 \%$ and Simmental accounts for about $3 \%$. Artificial insemination accounts for only $25 \%$ of population of cattle". "The spatial distribution of cattle showed a correlation with surfaces that are constantly a greater share of green crops in the agricultural structure, i.e., the meadows and pastures, as well as the areas where a lot of fodder crops grown" [26]. Precisely racial composition cattle influence that prevails in cattle dual-purpose production of milk meat, the emphasis is still on milk. Of the total volume of milk produced only $10-12 \%$ is 
delivered to dairies and industrial processes. Significant quantities of milk used to feed calves, because of their high cost and the difficulty in buying and milk. Other volumes are processed into various types of households in indigenous dairy products (mainly various types of cheese and cream cheese in part), and as such, in addition to work for their own consumption, placed on the market [29]. Ilk production in 2011, according to data from the Statistical Office of Montenegro [8] was 190.769 (ooo 1), with an average milk yield of about 3.2441 by milking cow. According to the Kalezić [21] production of beef in the period 1964/68 was in Montenegro $10.964,0$ tons.

Goat Production, passing a law to ban the keeping of goats (in 1954 in the former Yugoslavia), the number of these animals is very profitable, began rapidly to diminish, that would goats, almost disappeared from the mountain pastures of Montenegro. Damages that are caused by this, no one has tried to calculate, and probably that is impossible, because they are priceless. It took a long time to establish damage, which causes goats, are insignificant problem compared to deforestation by man. Injustice done to the goats, corrected in 1984, when he again legalized keeping goat [30]. Out of 32.756 agricultural households engaged in livestock, 3.583 agricultural holdings, or $10,97 \%$ is cultivated goats. Average number of goats per agricultural farm is 10 throats. The total number of goats (35.756 throat), which grows agricultural holdings in Montenegro is 3.583, of which family agricultural holdings (3.580) raised 35.001 throat and business subjects (3) 755 throat. Average number of goats per family agricultural household throat is 9,8, while the average number of goats in business subjects was 251,7 per throat business subject. According to Marković [31] today's goat in Montenegro is characterized by: (1) extensive or semi-extensive system, (2) goat was the lowest in the karts (Nikšić Cetinje, Cetinje, and part of Podgorica Coastal region), (3) herds with more than 10 goats (grant 2011) - 388 herds with 18.053 breeding animals (throat, on average, 46,5), (4) about half of the debris in the throat that is grown individually and which have significantly higher milk production and the number of cubs per goat. In terms of racial composition, population goats can be roughly dived into 3 groups: noble race (mostly Alpine and Saanen sporadically), throat of purebred type (domestic Balkan goat with more variety in color) and mongrels (through unplanned crossing of different varieties of domestic Balkan goats and noble breeds). "The positive trends in goat production lately manifested in are increase of the number of larger herds and increasing the number of throat per herd. According to the Ministry of Agriculture of Montenegro on the breeding goat premiums in the 2004 year, 200 farmers owned more than 30 breeding goats in the herd, the average of 75 throats.

The rest of the population is a small farm with 2 throats and 30 throats in the herd. According to the findings of the Biotechnical Institute in Podgorica, the average milk production per throat is $140 \mathrm{l}$, and the average production of about $15 \mathrm{~kg}$ of meat. Annual production of goat meat (young goat's meat and adult's throat) estimated at about 850 tons, and the annual milk production is estimate at 5.000 tons [29]. Goat Production may be important because of the additional household production in Montenegro, because in addition to income from milk, cheese, goats can produce twice as much skin as compared to other ruminants. In addition is most prolific goat ruminant (play 3 - 4 young goats per year).

The main economic task of pig farming is the production of meat for human consumption. Pigs from other animal species apart many characteristics: high fertility, more than two year far rowing (far rowing index 2-2.5) and the relatively short time gravidity (115 days), a high number of piglets at far rowing (8-12 piglets, depending on of the race, and many other factors: the age of the sow fertility, nutrition, housing ...), earliness intensively reared pig breeds, relatively quick introduction to reproduction (boar a 8 months, and sows according to body weight, usually between 6 and 7 months), relatively fast finishing pigs depending milk, 
quickly getting used to the transition to the feed mixture and concentrate components, in terms of feeding piglets are often fed forage mixtures, in which the proportion of nutrients that is, the proportion of each component in the concentrate according to the category of piglets and the phases of production and reproduction. The total number of agricultural holdings engaged in breeding pigs in Montenegro during the period 1960-2010, the reduced with 34.778 agricultural holdings of 13.469 , or $61,27 \%$. The agricultural census of 2010 listed the 13.465 family agricultural households in Montenegro, which are cultivated 41.118 pigs and 4-business subject, which are grown 6.555 animals. The average number of pigs per family agricultural household was 3,1, and an average of 409,7 pigs bred in business subject. The racial composition of the pig is prevalent: Domestic white meaty pig, Yorkshire, Dutch and Swedish Landrace. Crossbreeding and hybridization, the usual procedures for obtaining better results in swine, are not plan. As a result, a lot can be achieved modest results in terms of the number of pigs reared per sow and height increment. A relatively small number of farms that rise sows and thus produces about 15.000 pigs for slaughter, the average slaughter weight of $100 \mathrm{~kg}$. In addition is Serbia every year to import up to 40.000 pigs for fattening. Total pork production, in terms of a live weight gain of about 5.000 tons. Overall the relatively expensive inputs for production (mainly imported from the side), and for this level of production low cost live weight, does not seem to stimulate the development of the livestock industry [29].

Poultry rising in Montenegro is largely equal to the other branches of animal husbandry that is, ranking immediately after the cattle and sheep, the presence of livestock production. Due to the biological characteristics of poultry (high reproductive capacity, rapid growth, short generation interval, high feed efficiency) is possible in a short period to get high-value products (meat, eggs). On the other hand, maximum mechanization and automation of production enabled the industrial production takes on the character. Therefore, poultry is one of the profitable business of livestock, because in a short period with a small investment, can produce significant quantities of high-quality products that are in demand in the market, all the while competing products and adequate nutritional value. The eggs were after milk and meat, the most important foods of animal origin [32-33]. In addition to the human diet, eggs are a great practical value in industry (food industry, paint and varnish, for binding books, leather tanning, dyeing fabric ...). Furthermore, the chicken is indispensable in the diet of children, the elderly, convalescents [34-35].

Poultry has recently become an important source of meat and eggs all over the world, including Montenegro. The Census of Agriculture 2010 in Montenegro covers 16.313 agricultural holdings who breeding poultry 620.802 of which family agricultural holdings 411.086 breeding poultry and business subjects 209.716 . Average agricultural household has 38,1 poultry. Share of family agricultural holdings engaged poultry is $99,94 \%$. Yet a third of poultry breeding business subjects of $33,78 \%$, of which only 9 in Montenegro. Egg production in Montenegro in the period 1964/68 amounted to 20.544,2 pieces, and in 201175.804 or 169 pieces per hen. In extensive production in rural households, egg production has estimated at around 60 million units, mainly used for household consumption.

From the largest of poultry are domestic hen, crossbreds domestic and Styria, Leghorn... Other are poultry (ducks, geese, turkeys,), symbolically represented. "Faster development of poultry, especially poultry meat has contributed to the completion of the production process through the development of the sector of animal feed, parental flock of hybrids and the opening of the hatchery and production of day-old chicks, that modern slaughterhouse for poultry processing facilities and development "[29].

During the twentieth century to the present day, the number of horses in Montenegro decreases. This animal has be replace by motor vehicles and its importance in transport, 
agriculture and other industries is getting smaller. The Census of Agriculture in 2010 in Montenegro, data on the total number of horses, asses, mules and hinnies, regardless of their gender, age and use of storage that were on the farm. From 48.870 agricultural holdings: 2.741 family agricultural holdings cultivated 3.822 horses, 493 family agricultural holdings grown 575 donkeys, hinnies and mules.

The average number of horses per family agricultural household throat is 1,4 , while the average number of donkeys, hinnies and mule by family agricultural 1,2 farm throat. Growing the heavy working horses in Montenegro has suppressed, while the local mountain horse breeding out of control breeding services. What is even more worrying is the disappearance of the public sector, or state stud farm. Our research evidence based on similar studies Trajilović et al. [36], states that now the horse breeding on private initiative and there is no action plan to regulate the control of this particular branch of animal husbandry. Of course, the fact that the interest of the public focused on horseracing, equestrian sports and recreation, private initiative is mainly focus on breeding animals that correspond to these purposes. Indigenous breeds have not bred organized, and some interest in preserving venire or mountain horse does not provide real growth in their care.

Thus, it can be expected that the breeding of horses in Montenegro orients in three directions: (1) breeding racehorses, with the revival of traditional races, (2) the growing sport and recreational horses and throat for riding schools and specific purposes: treatment of psychosomatic illness and the mentally challenged (3) breeding horses for tourism: this would allow the preservation of local breeds adapted to their habitats and to contribute to the development of high-end tourism.

Due to favorable climatic and vegetation conditions in Montenegro, especially mountainous region with a diverse pasture for bees, large areas of grassland and pastures full of bee plants provide favorable natural conditions for the development of beekeeping. "Compared with other developed industrial countries, Montenegro is relatively clean and healthy nature, which results in the production of high-quality and healthy honey. On the one hand, in general, are very poorly have represent in the promotion and distribution of honey at the local or regional, and national level. On the other hand, the wealth of medicinal plants, whose properties have transfer to the honey made it possible to produce in Montenegro, the best types of honey on nutritional value, especially for medicinal properties, such as honey lime, meadow honey, and mountain honey forest honey. Besides its nutritional and dietetic value, honey has its application in therapeutic resources. In Montenegro, the honey is usually consume for breakfast with bread and tea, and is often used for making cakes (gingerbread), candy, confectioners; ice cream ...Production honey in Montenegro is well below the capabilities and environmental conditions.

The total number of agricultural holdings of 2010 dealing with the cultivation of bees is 2.533, of which almost all the family agricultural holdings, relations are more precisely 2.532 rearing 49.520 hive bees. Only one business subject in Montenegro has been dealing with bees, and has 252 hive bees. According to the Statistical Office of Montenegro [8], the total production of honey in Montenegro amounted to 394 tons, or $9 \mathrm{~kg}$ per hive. According to the Directorate for Development of Small and Medium Enterprises [37], yield of honey per hive depend on climatic and other natural conditions for the secretion of nectar and the type of beekeeping (stationary or migratory). With stationary beekeeping (share $60 \%$ ) yield per hive is from $10 \mathrm{~kg}$ to $30 \mathrm{~kg}$, and migratory beekeeping (share $40 \%$ ), honey production ranges from $20 \mathrm{~kg}$ to $60 \mathrm{~kg}$ per hive. Only a small portion of honey is sold through retailers, and mostly it is selling at markets or so-called sales house threshold. Honey consumption per capita inhabitants is small in Montenegro and is about 0.26 kilograms per inhabitants. It is important 
to note that, at current levels, the value of which have realize in this branch of agriculture was higher when beekeepers expanded range of bee products, it is engaged in the production of royal jelly, propels, pollen, nuts, selected... .

\section{CONCLUSIONS}

Our research record based on similar researches Bester et al [38], Nomura et al [39], Bramante et al [40], Aksoy et al [41], Rajović [42], pointed out is in first, several important conclusions:

1. In the period 1960-2010, the numbers of livestock units of livestock in Montenegro have reduce from 133,773 on $117,753.1$ or for 16,020 livestock units. Of total agricultural households in 2010 (32.675), they 32.656 dispose of 117.753 .1 conditional throat livestock while 19 business subjects have a at disposal 4891.2 conditional throat livestock.

2. The total numbers of agricultural farms that are with breeding sheep, the period 1960 2010 have been reduce from 38.942 agricultural farms on 6.088 or to $84.37 \%$. The total number of agricultural farms involved in breeding cattle, in the period $1960-2010$ has been reduce from 55.560 agricultural holdings on 24.624 or $55,68 \%$. Total number of goats (35.756 throat) that raised agricultural holdings in Montenegro is 3.583, of which family agricultural holdings (3.580) grown 35.001 throat and business subjects (3) 755 throat. The average number of pigs per family agricultural household was 3.1 , and in average is 409.7 pigs grown on business subjects. Census agriculture in 2010 in Montenegro covers 16,313 agricultural holdings that breed 620.802 pieces poultry, of which family agricultural holdings grown 411.086 pieces poultry and business subjects 209. 716. The average number of horses per family agricultural household is 1.4 throats, while the average number of donkeys, hinnies and mule by family agricultural household 1.2 throats. Total number of agricultural holdings of 2010 involved in breeding of bees is 2.533, of which almost all the family agricultural holdings, respectively more precisely 2.532 who grown 49.520 hives bees. Only one business subjects in Montenegro deals breeding bees respectively owns 252 beehives bees.

3. The total meat production in the period $1964 / 68$ to Montenegro amounted to $10.964,0$ tons, of which on beef meat 3.693,0 tons of waste, mutton 3.559,0 tons, pork 3.347,0 tons and poultry 365.0 tons. Total milk production in the same period amounted to in Montenegro 57.710,4 (ooo 1), and egg production 30.826,0 pieces. The average production of cow of milk per agricultural household in 1967 amounted to 1.4281 of the sheep 5401,694 pieces of egg production and wool $26 \mathrm{~kg}$. The total meat production in the period 2001/02 in Montenegro amounted to 13.330 tons, of which on beef meat accounted for 8.500 tons, mutton 4.830 tons, pork about 5.000 tons. Total milk production in Montenegro 2011 amounted to 202.449 (oool), of which on cow's milk accounted for 190.769 (oool) per dairy cow 3.244 1, milk from the sheep 8.830 (oool) by sheep 791 . Total egg production during the same period amounted to 75,804 units, by hen 169. Honey production amounted to 394 tons, per hive $9 \mathrm{~kg}$.

4. In Montenegro, we highlight two types of livestock production and to semi-nomadic and stationed. Total number of agricultural holdings that raise cattle was 32.675, of which $18,9 \%$ or 6.166 agricultural holdings which have a semi-nomadic way of breeding cattle and 26.509 or $81,1 \%$ agricultural holdings have a stationed system of 
livestock production. Holdings that have a semi-nomadic way of livestock them 6.166 the holdings of livestock grazing on common land (summer pasture, commune).

5. In all branches of the livestock sector in Montenegro, there is significant potential for the development of organic livestock production, especially in mountainous areas. Code cattle, sheep and goat predominant racial composition of the traditional livestock on pastures in mountainous areas, and preserved the traditional making of indigenous species of dairy products (cheese and milk cream) on agricultural holdings, favors the development of organic livestock production. Also, a huge natural potential and the presence of large areas of meadows and pastures (450.943 ha) which is not used rationally because of decades of continuous decline in the number of livestock in Montenegro. Through measures applied for the improvement of livestock, the state is trying to reverse this trend, where in the lowland areas of the subject of work focus on cattle raising (meat and milk), and in the mountainous area on sheep, goat and cattle production [43-44].

6. In recent decades, livestock Montenegro have reduce, in a word disappears. In order to keep the population in rural areas, necessary to invest more in the livestock development, development of farm cooperatives liven, to invest in the infrastructure of the village, establish small enterprises of the processing factory for milk and meat, a young farmer from the state especially encouraged to remain the countryside. Agriculture and the village, developed in sustainable system, it is essential that over the long-term development strategies and regulating relationships and obligations that the strategy to be fully state obligation and responsibility to livestock breeding grasp and to accept as the backbone of economic development of a country village as a necessity, and historical development of facts. Agriculture Development Strategy should clearly define macro-zones on which to foster specific livestock species, and based on that subsidizes and assists farmers and households. Law concerning land is necessary to clearly specifies, it is defines the terms of use and disposition of land for the purpose of food production. It should be clear that the specifies how and under what conditions will be used state lands, what about the natural meadows and pastures, by taking advantage of available forest land for livestock [45].

Finally, the role of the Montenegrin villages and agriculture must be first class, because of its potentials, the main power future development of Montenegro. "This requires radically new relationship between society and science according to village and agriculture.

Instead of the existing approaches in which they treated as preventive producers of cheap food, must develop a new concept, a comprehensive rural development, which will be based on demographic, natural, economic and socio-cultural resources" [46]. Responsible role in formulating rural development in Montenegro, which will be based on the natural and socioeconomic potential of rural areas, should certainly have and geographical Sciences, who their access should to consolidate research efforts and the results of other scientific disciplines [4753].

\section{References}

[1] Visit Montenegro, Available from: http://www.visit-montenegro.com (20.09 2013).

[2] Rajović G., Bulatović J., International Research Journal of Life Sciences 1(2) (2013) $1-18$.

[3] Rajović G., Journal of Road and Traffic Engineering 58(4) (2012). 
[4] Rajović G., Journal Economics 53(3-4) (2007) 58-67.

[5] Rajović G., Journal Economics 55(1-2) (2009) 103-114.

[6] Rajović G., Bulatović J., International Letters of Natural Sciences 6 (2014) 57-68.

[7] Rajović G., Bulatović J., Tactful Management Research Journal 2(6) (2014) 1-11.

[8] Cenzus agriculture, Cenzus agriculture, Podgorica: Office of Statistics Montenegro, 2012.

[9] Doderović M., Ivanović, Z., Matica Crnogorska, Spring (2011) 463-474.

[10] Rajović G., Bulatović J., Larhyss Journal 17(17) (2014) 115-133.

[11] Rajović G., Journal Industry 39(3) (2011) 261-280.

[12] Rajović G., Bulatović J., Scientific Electronic Archives 5(1) (2014) 5-21.

[13] Rajović G., Journal of Agricultural and Food Science Research 1(1) (2012) 11-25.

[14] Schiere J. B., Ibrahim M. N. M., Van Keulen H., Agriculture, ecosystems \& environment 90(2) (2012) 139-153.

[15] Dorward A., Anderson S., Nava Y., Pattison J., Paz R., Rushton J., Sanchez Vera E., A guide to indicators and methods for assessing the contribution of livestock keeping to the livelihoods of the poor, Imperial College: Department of Agricultural Sciences, 2005.

[16] Rajović G., Bulatović J., American-Eurasian Journal of Agricultural \& Environmental Sciences 12(12) (2012) 1558-1571.

[17] Rajović G., Bulatović J., Open Journal of Social Science Research 1(7) (2013) 169-173.

[18] Herrero M., Thornton P. K., Gerber P., Reid R. S., Current Opinion in Environmental Sustainability 1(2) (2009) 111-120.

[19] Thornton P. K., Philosophical Transactions of the Royal Society B: Biological Sciences 365 (1554) (2010) 2853-2867.

[20] Some problem of socio-economic trends in rural areas, Belgrade: Institute of Agricultural Economics, 1963.

[21] Kalezić Ž., Structural changes in Montenegrin village in the twentieth century, Titograd: Victory, 1976.

[22] Cenzus agriculture, Podgorica: Office of Statistics Montenegro, 2003.

[23] Rajović G., Journal Montenegrina (Natura Montenegrina) 9(2) (2010) 205-214.

[24] Rajović G., Bulatović J., Hyperion Economic Journal 1(4) (2013) 28-42.

[25] Rajović G., Bulatović J., Applied Journal of Hygiene 2(3) (2013) 15-24.

[26] Jaćimović B., Journal of the Geographical Institute of the Faculty of Sciences 25 (1978) 47-57.

[27] Tomić P., Proceedings of the Faculty of Sciences 13 (1984) 11-19.

[28] Gutić M., Petrović M., Bogosavljević-Bošković S., Kurćubić V., Mandić L., Dosković V., Sheep farming - production technology, Faculty of Agriculture, Istituto Sperimentale Italiano"Lazzaro Spallanzani, Čačak, 2006. 
[29] AMIS - Agricultural Marketing Information System of Montenegro, Available from: http://www.amiscg.org (21.09 2013).

[30] Urošević M., Mihajlović Z., Đurić M., Journal Biotechnology in Animal Husbandry 41(1-2) (1987) 23-25.

[31] Marković M., Value chain in the dairy sector in Montenegro, Available from: http://www.etf.europa.eu (22.09 2013).

[32] Smil V., Food production. The nutrition transition: Diet disease in the developing world, 2002.

[33] Smith J., Sones K., Grace D., MacMillan S., Tarawali S., Herrero M., Animal Frontiers 3(1) (2013) 6-13.

[34] Badubi S. S., Rakereng M., Marumo M., Res. Rural Dev. 18(1) (2006).

[35] Kingori A. M., Wachira A. M., Tuitoek J. T., International Journal of Poultry Science 9(4) (2010) 309-316.

[36] Trailović, D., Petrujkić, T., Vučinić, M., Trailović, D., Katrinka, Z., Modern Trends in breeding and Health Protection of horses, Available from: http://www.academia.edu (2409 2013).

[37] Directorate for Development of Small and Medium Enterprises, The business climate in small and medium-sized enterprises, Available from: http://www.nasme.me (25.09 2013).

[38] Bester J., Matjuda L. E., Rust J. M., Fourie H. J., The Nguni: a case study, Community based management of animal genetic resources (2003).

[39] Nomura T., Honda T., Mukai F., Current Topics in Genetics 1 (2005) 59-71.

[40] Bramante G., Roma R., Pieragostini E., NEW MEDIT 6(2) (2007) 52.

[41] Aksoy A., Kulekci M., Kaya T.E., Journal of Animal and Veterinary Advances 8(2) (2009) 348-349.

[42] Rajović G., Journal Economics 55(1-2) (2009) 103-114.

[43] Rajović G., Bulatović J., International Letters of Social and Humanistic Sciences 3 (2013) 37-45.

[44] Rajović G., International Letters of Social and Humanistic Sciences 11 (2013) 35-46.

[45] Lazić M., Perspectives on Rural Development (IV), Available from: http://www.agroplus.rs (26.09 2013).

[46] Institute for the Study of the village, About us, Available from: http://www.proučavanjesela.rs (27. 09 2013).

[47] Rajović G., Bulatović J., International Letters of Natural Sciences 1 (2014) 33-53.

[48] Rajović G., Bulatović J., International Letters of Social and Humanistic Sciences 9 (2014) 81-99.

[49] Rajović G., Bulatović J., Middle-East Journal of Scientific Research 18(3) (2013) 382-388. 
[50] Rajović G., Bulatović J., Journal of Sustainable Development Studies 3(2) (2013) 136-167.

[51] Rajović G., Bulatović J., Journal of Studies in Social Sciences 2(2) (2013) 105-133.

[52] Cerasela Vintilescu, International Letters of Social and Humanistic Sciences 13 (2014) 58-63.

[53] Banović B., Mijatović-Dukić M., Joksić N., Teme 37(3) (2013) 1281- 1302. 